\title{
UM OLHAR BENJAMINIANO SOBRE A VIDA QUE NINGUÉM VÊ DE ELIANE BRUM (REFLEXÕES SOBRE O OFÍCIO DE CRONISTA- JORNALISTA)
}

Vinícius Canhoto

\begin{abstract}
RESUMO
O presente artigo aborda a questão da relação entre o narrador e historiador segundo Walter Benjamim, confrontando-a com as crônicas-jornalísticas de Eliane Brum. Busca articular conceitos teóricos benjaminianos para problematizar o trabalho do historiador/cronista e do narrador/jornalista, relacionando-os à obra de Brum no contexto historiográfico atual.
\end{abstract}

Palavras-Chaves: Narrador. Cronista. Historiografia.

\section{A BENJAMINIAN LOOK AT THE LIFE NO ONE SEES FROM ELIANE BRUM (REFLECTIONS ON THE OFFICE OF CHRONIST-JOURNALIST)}

\begin{abstract}
This article addresses the question of the relationship between the narrator and historian Walter Benjamin second, comparing it with the chronic-journalistic Eliane Brum. Seeks to articulate theoretical concepts benjaminianos to question the work of the historian/chronicler and narrator/journalist, relating them to the work of Brum in the current historiographical context.
\end{abstract}

Key Words: Narrator. Chronicler. Historiography.

\section{Introdução}

A tese $n^{\circ} 3$ sobre o conceito da história de Walter Benjamin traz para nós a figura do cronista (Chronist). A primeira coisa que podemos nos perguntar é a respeito da escolha pelo termo cronista e não historiador para um texto que tem por título uma tese que trata da história. No primeiro momento, podemos nos remeter ao deus Chronos, deus do tempo, do qual deriva o tempo cronológico, que devora seus filhos ao estabelecer uma seqüência mensurável, associada ao movimento linear de uma ordem que possui um princípio e um fim, ordem Escritor, doutor em Filosofia pela Universidade Federal de São Paulo. Brasileiro, residente em São Paulo-SP. E-mail: dicionariodebabel@hotmail.com 
subvertida por Zeus que, ao matar Chronos, estabeleceu a imortalidade. No segundo momento, nos remetemos ao cronista enquanto escritor, autor cotidiano, historiador, em suma, é aquele que nos recorda d' $O$ Narrador (Erzähler), de 1936, como aquela autoridade capaz de transmitir uma experiência que passa de pessoa para pessoa. Na perspectiva benjaminiana, o cronista é o narrador da história. Não é o caso do jornalista que surgiu no seio da imprensa no alto do capitalismo. O tema do declínio da arte de narrar está relacionado ao modo de vida da sociedade capitalista, que desenvolveu novas formas de expressão como o romance e a informação jornalística. A arte de narrar era diretamente vinculada ao lento trabalho manual nas sociedades précapitalistas, cujas raízes estão na tradição oral. Portanto, o ato de contar e recontar a mesma história através de gerações deu lugar à exigência do novo e da novidade como prática da imprensa que se destacou pela forma de comunicação superficial e acelerada que é a informação. Um exemplo dado pelo autor é a fórmula do fundador do jornal Figaro, Villemessant, ao dizer que para seus leitores um incêndio num sótão do Quartier Latin era mais importante que uma revolução em Madri. Ou seja, na época da imprensa, saber a respeito dos acontecimentos mais próximos, as informações de verificação imediata e a notícia das cercanias, se tornaram mais importantes que os saberes vindos de longe. Na narração, a distância espacial, como a distância temporal eram fundamentais, pois a narrativa impunha a exigência de um afastamento temporal e uma distância que possibilitasse a formação de um ângulo de observação. Embora recebamos diariamente notícias de todo o mundo, somos pobres em histórias surpreendentes porque os fatos já nos chegam carregados de explicações. A informação só tem valor, constata Benjamin, no momento em que é nova. Deste modo, a notícia é natimorta e perecível, ciosa de novidade. De modo distinto, a crônica mantém a memória viva daquilo que poderia estar morto, porém mantém o eco das vozes que emudeceram, de tal forma que o cronista benjaminiano não faz senão narrar os acontecimentos, sem a distinção entre os grandes e pequenos eventos, levando em consideração de que nada do que tenha ocorrido poderá ser perdido para a história.

Para Benjamin, a tarefa do historiador não é buscar um passado sepultado, mas de reconstruí-lo a partir daquilo que o passado deixou de 
destroços, ruínas e cacos. Trata-se de ir além de contar as histórias que não foram contadas, a história dos vencidos, como também despertar os mortos e juntar os destroços, reconstruir o passado para redimi-lo e libertá-lo, construir, no presente, o futuro do passado irrealizado. A salvação do passado está na libertação e no futuro do passado que pode se tornar presente na redenção da memória das gerações mortas, renascidas naquilo que o passado não realizou, mas que pode ressucistar a esperança e o futuro que não foram possíveis.

A partir da problemática benjaminiana do declínio das ações da experiência, coletiva e compartilhada, que ocorre na aceleração do tempo na modernidade capitalista, não se encontram mais momentos para ouvir histórias e compartilhar, como fontes de transmissão de saberes práticos fundadas na experiência da tradição coletiva, optando-se pela imprensa como fonte de informação concisa e de fácil assimilação, que não se integra à experiência do indivíduo, deixando-o pobre nestes termos em razão da vida determinada pelo imediatismo e efemeridade. Além disso, o ato de narrar que se constituiu tradicionalmente de forma artesanal, cotidiana, uma atitude contemplativa e imaginativa nos impõe a partir da exigência de certa distância e de determinado ângulo de observação e interpretação que são inexistentes no jornalismo, que preza pela proximidade, subjetividade e sentimentalidade dos envolvidos, bem como a interpretação editorial e previamente dada. A partir da concepção benjaminiana, como podemos aproximar as crônicas-jornalisticas de Eliane Brum das formulações de narração e história em Walter Benjamin? Sob qual experiência se constrói o olhar e o discurso cronista de Brum que privilegia a proximidade e não transmite nenhum conselho?

O objetivo deste artigo é o de abordar a obra $A$ Vida que Ninguém Vê de Eliane Brum (2009), apresentando suas crônicas-jornalísticas como exemplos de narrativas sem moral ou ensinamento. Para tanto, vamos articular conceitos teóricos benjaminianos para problematizar o ofício do historiador/cronista e do narrador/jornalista. 


\section{Jornalismo-narrativo ou a história dos "sem história".}

Benjamin afirma em O Narrador (1936) que as ações da experiência estão em baixa e, ao que tudo indica, tais experiências continuarão caindo até que seu valor desapareça de todo. Como exemplo, o autor cita o jornal cujo nível estava mais baixo que nunca, e que da noite para o dia não somente a imagem do mundo exterior, mas também a do mundo ético, sofreram transformações que antes não seriam julgadas possíveis. Sob a constatação benjaminiana, havia o contexto da Primeira Guerra Mundial, a estratégia da guerra de trincheiras, a economia no período de inflação, o corpo na guerra material e a ética dos governantes, exemplos aos quais o autor atribui uma pobreza de experiência e ausência de conhecimentos que pudessem ser transmitidos. Este mesmo argumento é encontrado no texto Experiência e Pobreza (1933) onde o autor constata que estamos mais pobres em experiências comunicáveis. Giorgio Agamben (2005) atualiza esta crítica e vai mais além ao dizer que hoje sabemos, que para a destruição da experiência, uma catástrofe não é necessária, a pacífica existência cotidiana em uma grande cidade é, para esse fim, perfeitamente suficiente. Mais adiante, o autor diz que a experiência tem seu correlato não no conhecimento, mas na autoridade, ou seja, na palavra e no conto, e hoje ninguém mais parece dispor de autoridade suficiente para garantir uma experiência, e se dela dispõe, nem mesmo Ihe aflora a idéia de fundamentar em uma experiência a própria autoridade. A autoridade a qual Agamben se refere não é a autoridade que identificamos com a figura autoritária ou autoritarismo, a autoridade aqui se refere ao auctoritas romano, ou seja, a personalidade, a autoria.

Esta autoria e personalidade fundamentada na singularidade de um determinado saber pode ser encontrada na obra $A$ Vida que Ninguém Vê (2006), escrita pela jornalista Eliane Brum. Crônicas que foram originalmente escritas e publicadas no jornal Zero Hora de Porto Alegre. Nas Teses Sobre o Conceito de História, o cronista "narra os acontecimentos, sem distinguir entre os grandes e os pequenos, leva em conta a verdade de que nada do que um dia aconteceu pode ser considerado perdido para a história" (BENJAMIN, 1996, 223). As 
crônicas de Brum contrastam com aquilo que se convencionou chamar de “jornalismo padrão”, ou seja, a pauta jornalística voltada para os grandes acontecimentos ou fatos que envolvem a vida de personalidades políticas e econômicas, de pessoas famosas através do sucesso, das celebridades fabricadas pelo mecanismo da publicidade e do consumo. Ao lançar o olhar sobre aquilo que não é visto, o jornalismo de Brum abandona a atrofia da experiência e a pobreza da vida do espírito massificado pelo consumo ao construir a historiografia da vida dos homens infames, capaz de "escutar e fazer ouvir a linguagem que vem de fora ou de baixo" que abre mão "do lado do poder, do que ele diz ou faz dizer" (FOUCAULT, 1992, 92). Na medida em que reconstrói a memória de um mundo sem memória, Brum escreve sobre pessoas sem fama ou glória que jamais seriam manchetes na grande imprensa. Ao colher a voz de quem não tem voz, a autora quebra o silêncio dos homens anônimos na História. Em suas narrativas, a experiência do outro se transforma em nossa experiência comum, cambiável. Neste contexto, Brum compõe, por meio do trabalho e da oralidade de suas crônicas, uma historiografia daqueles que tradicionalmente não tinham história, o paradoxo dos sujeitos históricos excluídos das grandes narrativas historiográficas.

A Vida que Ninguém Vê (2006) inicia a partir da visão de Brum de que o olhar é redentor: "O mundo é salvo todos os dias por pequenos gestos. Diminutos, invisíveis. O mundo é salvo pelo avesso da importância. Pelo antônimo da evidência. O mundo é salvo por um olhar". A crônica "História de um Olhar" tem como protagonista um rapaz de nome Israel, um vagante da Vila Kephas na cidade de Novo Hamburgo, interior do Rio Grande do Sul. À margem do padrão de normalidade, à deriva das convenções de sua comunidade, Israel era assim descrito:

\footnotetext{
Imundo, meio abilolado, malcheiroso, Israel vivia atirado num canto ou noutro da vila. Filho de pai pedreiro e de mãe morta, vivendo em uma casa cheia de fome com a madrasta e uma irmã doente. Desregulado das idéias, segundo o senso comum. Nascido prematuro, mas sem dinheiro para diagnóstico. Escorraçado como um cão, torturado pelos garotos maus. Amarrado, quase violado. Israel era cuspido. Era apedrejado. Israel era a escória da escória. (BRUM, 2006, 12)
} 
Este personagem da vida real, semelhante a tantos outros vagantes nas ruas, teve sua redenção quando Israel seguiu um menino até a escola para onde o garoto se dirigia, todas as tardes. No interior da escola a professora do garoto descobriu alguém que da janela olhava para dentro, cantava no lado de fora, desenhava com os olhos.

Eliane viu Israel. E Israel se viu no olhar de Eliane. E o que passou naquele olhar é um milagre de gente. Israel descobriu um outro Israel navegando nas pupilas da professora (BRUM, 2006, 24).

Tal troca de olhares era, além da descoberta da alteridade, a possibilidade pedagógica de resgate de Israel que a cada dia dava um passo para o olhar da professora e para o interior a sala de aula. A conseqüência disso foi que Israel ingressou na escola, ganhou materiais escolares, chegou no dia seguinte de banho tomado, barba feita e roupa nova. "A redenção de Israel foi a revolução da professora" (BRUM, 2006, 25). Tal regeneração atingiu a professora que vivia deprimida, de mal com a vida, que parou de reclamar e passou a rir e a chorar de emoção; e a Israel que, no 7 de Setembro, desfilou pintado de verde-amarelo e toda a comunidade da Vila Kephas, que o compreendeu e assimilou, o aplaudiu de pé no dia da Independência.

Este espírito redentor não está presente em "Enterro de Pobre". A crônica poderia se chamar "O Caminho do Pobre" caso a autora tivesse se apropriado de uma das falas do protagonista, Antonio Antunes, um homem que acabara de sepultar o filho recém nascido. "Não há nada mais triste do que enterro de pobre. Porque o pobre começa a ser enterrado em vida". Estas são as palavras de Antonio, um abatedor de árvores da região carvoeira, resignado com a cova rasa e o caixão doado para enterrar o bebê de 960 gramas que morrera ainda no ventre da mãe. A tragédia familiar de Antonio ocorreu em uma sexta-feira quando sua esposa, que cuidava da filha de seis anos que jamais caminhou,

sentiu a quentura do sangue correndo pelas pernas (...) quando avisou a moça do hospital do que se passava no ventre. Foi despachada para casa, com a explicação de que não era nada. O sábado mal tinha nascido quando Antonio carregou a mulher de volta à casa da saúde. No final da manhã, quando pouco tinha sido feito, Antonio venceu sua humildade atávica e ameaçou a chamar a polícia. Então exportaram os dois a Porto Alegre, onde chegaram tarde demais. Salvaram a mãe, o bebê estava morto. Desde quando, não se sabe. No domingo, o filho 
de cinco anos, que como a irmã nunca caminhou, desembarcou da ambulância para a UTI de um hospital da capital. Descobria-se que estava com pneumonia quando há dias era tratado para outra coisa. $\mathrm{E}$ lá continua até hoje, com o pai duelando no saguão contra a morte (BRUM, 2006, 37-38).

O caminho ou a epopéia do pobre se passou entre hospital e o cartório em mais de uma viagem de ida e volta porque no hospital os funcionários se esqueceram de carimbar e assinar o atestado de óbito. Caminha por quilômetros a pé porque não tinha dinheiro para a passagem. De estômago vazio, Antonio estava acompanhado pela cunhada que 15 dias antes perdera seu próprio filho nascido morto. Ainda no hospital,

\begin{abstract}
Antonio quis espiar a face do filho por um momento, mas a funcionária que foi buscar a criança na geladeira não deixou. Antonio tinha comprado uma roupinha de sete reais no centro de Porto Alegre para que o filho não fosse sepultado nu como um rebento de bicho. Mas não pôde vesti-lo. Restou a Antonio o caixãozinho branco que ninou nos braços até a cova número 2026 do Campo Santo do Cemitério da Santa Casa (BRUM, 2006, 36).
\end{abstract}

A crônica-jornalística de Brum transcende o jornalismo ordinário e se transforma em historiografia na medida em que seu texto se transfigura em narração consciente da injustiça do presente e atribui visibilidade ao invisível e encontra, no factual, o histórico. Ao narrar a tragédia de Antonio, apresenta em seu texto um fragmento cultural de nossa época, incapaz de dar dignidade aos pobres:

Deixa para trás o filho sem nome, sepultado numa cova rasa, sem padre e sem flor. Porque a cova de pobre tem menos de sete palmos, que é para facilitar o despejo do corpo quando vencer os três anos de prazo. Então é preciso dar lugar a outro pequeno filho de pobre por mais três anos. $E$ assim sucessivamente há 500 anos (BRUM, 2006, 39).

Nesta história não há vencedores, todos nós dotados de humanidade saímos derrotados. A rememoração deste episódio não nos permite falar em progresso "que não represente um acréscimo de felicidade e de perfeição nos mesmos espíritos que antes sofreram sob condições imperfeitas" (LOTZE, apud. BENJAMIN, 2006, 521). Nesta história não há reparação, todos nós saímos humilhados e ofendidos. 
Debaixo de cada uma das mais de duas mil cruzes semeadas na terra fofa do Campo Santo há uma sina como a de Antonio. Para entender o resto da história que ainda virá é preciso conhecer o que é a morte do pobre. É necessário compreender que a maior diferença entre a morte do pobre e a do rico não é a solidão de um e a multidão do outro, a ausência de flores de um e o fausto do outro. Não é nem pela ligeireza de um e a lerdeza do outro. A diferença maior é que o enterro de pobre é triste menos pela morte e mais pela vida (BRUM, 2006, 39).

Todavia a vida que ninguém vê não é prerrogativa apenas dos pobres. A história dos traslados da estátua do Conde de Porto Alegre revela isso. A crônica "O Conde Decaído", não apenas questiona os "heróis" e as "personalidades históricas", como também a própria construção de desconstrução do "herói histórico". Brum fala da fugacidade da fama e da efemeridade da glória:

\begin{abstract}
Ele, o Conde de Porto Alegre. Manoel Marques de Souza. Terceiro varão de uma dinastia de centauros de espada em riste. Parido na guerra, pela guerra. Engatinhando nas poças de sangue dos campos de batalha, a pele do rosto feita couro pelos ventos do pampa. Aos 13 anos despedindo-se da casa da mãe para se entreverar com os castelhanos. Aristocrata da guerra, virou barão, visconde e por fim um conde, os dois últimos na Guerra do Paraguai. Morreu embebido em dores e feitos, a mortalha bordada de galões e medalhas. $E$ era tão importante, mas tão importante, o nome estendido como um pelego de brios sobre as coxilhas do Rio Grande, que mereceu a primeiríssima estátua cravada na mui leal e valorosa Porto Alegre (BRUM, 2006, 66).
\end{abstract}

O tom irônico e grandiloqüente da narrativa tem o propósito de demonstrar a decadência de um "herói" e "vencedor" histórico, que teve suas glórias imortalizadas, no ano de 1885, em uma estátua de mármore, colocada na Praça Pedro II, sob discurso da Princesa Isabel. Decadência que começou em 1889, quando a República renomeou a praça para Marechal Deodoro da Fonseca e substituiu a estátua do Conde de Porto Alegre pela de Júlio de Castilhos. A estátua do Conde foi removida então para a Praça do Portão. Este episódio foi registrado pelo jornal do partido republicano, A Federação, e ironizado por seu concorrente Correio do Povo:

A Federação ainda teve o desplante de registrar que a "estatua ficou collocada num lugar de bastante destaque, fazendo frente para o ponto mais transitado da praça". No que foi raivosamente contestada em crônica de Mário Totta nas páginas do concorrente Correio do Povo: "E correram-te da praça... O que os inimigos da tua pátria nunca puderam fazer, (...) os teus patrícios fizeram-te ainda ontem - desalojaram-te. Vivo tu, ninguém o faria; morto correram-te" (BRUM, 2006, 68-69). 
A autora ainda nos informa que por volta de 1970 a estátua do Conde foi virada, hoje seu olhar está condenado à tediosa visão de uma loja de artigos de cama, mesa e banho; sua espada se quebrou nas locomoções. Desprovida da espada, do poder, da fama e da glória, a simbologia da estátua não poderia ser mais melancólica: "No fim tudo é pó. Esquecimento. E o inconfundível cheiro de urina. (...) $\bigcirc$ Conde de Porto Alegre reduzido a uma vida que ninguém vê num canto da cidade" (BRUM, 2006, 69).

Neste contexto, falar em nova história é discutir a proposição da inclusão de memórias de sujeitos que nunca foram objetos de pesquisa histórica. Brum, ao relatar a vida de dois mendigos, traz para primeiro plano a perspectiva da história vista, sob outro ângulo, o de baixo. A autora afirma que tal procedimento não é um truque banal, "é uma alteração de foco que se faz em apenas um segundo e uma inclinação de alguns centímetros do pescoço, mas que resulta avassaladora" (BRUM, 2006, 189). No entanto, esta inversão metodológica e de perspectiva traz outros signos e sentidos para a prática jornalística, ou seja, uma abordagem que envolve a inclusão de memórias, construção de identidades por meio de novos personagens para apresentar uma nova maneira de entender e propor novos olhares para o discurso que é construído em meio à complexidade cotidiana:

\footnotetext{
A vida que ninguém vê me impôs - e não foi fácil - curvar o pescoço, me agachar e colocar meus olhos no mesmo plano dos olhos dele. Dessa posição de igualdade, pude enxergá-lo. Bastou olhar para baixo para que Sapo pudesse me contar como era olhar para cima (BRUM, 2006, 189).
}

Sapo estava na Rua da Praia esmolando há 30 anos. Para recolher sua história, a jornalista teve, segundo ela, de se agachar e nivelar seus olhares, subvertendo a regra do jogo em que ambos participavam. Apesar de não se reconhecerem neste nivelamento, ela descobriu, entrevistando-o, que ele, tal qual uma formiga, trabalha no verão para descansar no inverno, estação que é capaz de tornar a laje da Rua da Praia em lápide. Descobriu também que para a sobrevivência:

Sapo, como a maioria dos pedintes do Centro, não está lá sozinho. É longa - e invisível - a rede que se estende por trás de cada um deles. 
Sapo tem uma espécie de segurança e motorista, Rogério Rodrigues, 53 anos, e uma namorada, Márcia Luiza dos Santos Carvalho, 34 anos. Os dois o acompanham durante a jornada, de segunda a sexta, das $9 \mathrm{~h}$ às $18 \mathrm{~h}$. Às vezes também no sábado. Rogério era taxista, 35 anos de trânsito, e costumava levar Sapo para casa, na Vila São Francisco, em Guaíba. Teve uma ameaça de enfarte e os dois fizeram um acordo. Ele, aparelho celular na cintura, protege Sapo na guerra do Centro, pela comida e mais uns $R \$ 15$ por dia. Quando Sapo ganha bem, Rogério o leva para casa por $\mathrm{R} \$ 30$. Quando não ganha o suficiente, Sapo tem de ir embora de ônibus. Na maioria dos dias, Rogério recebe, pelo "trabalho", uns R\$45. No fim do mês embolsa perto de mil reais. Márcia, mais conhecida como Baixinha, não. É a companheira de Sapo. Ela cuida dele, faz comida, dá banho, lava a roupa no barraco de duas peças. Em troca, ele sustenta a mulher e suas quatro filhas, no casebre ao lado (BRUM, 2006, 39).

Outro personagem, descoberto por Brum, chamado Geppe Coppini talvez sequer possa ser chamado de mendigo "porque nunca pediu nada. Não há ninguém, em toda Anta Gorda, que possa afirmar que Geppe tenha pedido alguma coisa" (BRUM, 2006, p. 42). Esta figura, náufraga da modernidade por conta de destinação ou simplesmente uma praga rogada por uma cigana na sua infância, cresceu acariciando as árvores, colhendo frutas e legumes dos pomares, dormindo em celeiros, nunca trabalhou, nunca produziu, embora tivesse "carteira de trabalho orgulhosamente em branco, folha por Folha" (BRUM, 2006, 44).

Nas crônicas de Brum há um colecionador de coisas jogadas fora que peregrina pelas ruas de Porto Alegre, de lixeira em lixeira, recolhendo de restos da cidade. "Oscar Kulemkamp apropriou-se dessas vidas jogadas fora. E salvouas do aterro sanitário do esquecimento. (...) Oscar Kulemkamp teceu sua colcha de retalhos com a vida dos outros. Com o refugo da vida dos outros" (BRUM, 2006, 49). Tal atitude é interpretada como uma jornada sem fim para salvar os pedaços da cidade da implacável cultura de consumo que torna tudo descartável. Trata-se da mesma cidade que coloca a cabeça de um menino de dez anos a prêmio. Um menino, louco por cavalos, que não gostava de bola ou bicicleta, teve sua cabeça prometida por cinqüenta reais.

O crime do menino foi montar no cavalo do carroceiro e galopara com ele pelas avenidas da cidade. (...) O cavalo, desacostumado a galopar sem as viseiras de seu jugo perdeu-se do cavaleiro. O menino voltou para a periferia desmontado, tendo como lembrança da aventura apenas um traseiro em feridas. O carroceiro perdeu o instrumento de trabalho, o único ganha-pão da filharada. Enfureceu-se. Botou preço e espalhou pela capital. Como essa não foi a primeira cavalgada do 
menino, outras vítimas se uniram ao carroceiro. Desde o início do ano o menino está jurado de morte a um preço menor que o de um cavalo (BRUM, 2006, 84-85).

O mesmo fascínio pelo cavalo e pela montaria foi a que inspirou Vanderlei Ferreira a sair de Uruguaiana, fronteira com Uruguai e Argentina, para ir, ora a pé, ora de carona, durante três dias, em direção a uma feira de agronegócio, Expointer, que ocorre em Esteio, na região metropolitana de Porto Alegre. Este personagem estava acompanhado de um cabo de vassoura o qual apresentou

\begin{abstract}
como seu cavalo. Pediu atestado sanitário para que o animal botasse os cascos na feira. Demonstrou todos os movimentos do Freio de Ouro, o grande prêmio da raça crioula, evolucionando com seu cavalo de pau. E assim inaugurou sua participação na grande festa do Rio Grande (BRUM, 2006, 106).
\end{abstract}

Tal atitude tratava-se de uma ludicidade que o libertava da loucura de viver a realidade pobre de quem nunca foi à escola, mas freqüentava a Faculdade de Zootecnia, assistindo aulas e, às vezes, até fazendo prova. Brum comenta que se fosse levar a vida a sério, Vanderlei Ferreira descobriria que era analfabeto, portanto, decidiu que a distância entre a realidade e a liberdade é um cabo de vassoura. "Sem invenção, diz Vanderlei Ferreira, a vida fica sem graça. Fica tudo muito difícil" (BRUM, 2006, 110). Invenção como a de Vany Pontes e Celina Costa, idosas paralíticas, internas de um asilo, que aprenderam a pintar e transformaram suas obras em uma comunicação com o mundo do qual estavam exiladas.

Mais que histórias desconhecidas de pessoas sem glória ou fama, a autora conta, por exemplo, um episódio verídico, com requintes de conto fantástico, como a que envolve um macaco humanizado:

O Zoológico de Sapucaia do Sul abrigou um dia um macaco chamado Alemão. Em um domingo de sol, Alemão conseguiu abrir o cadeado e escapou. Ele tinha o largo horizonte do mundo à sua espera. Tinha às árvores do bosque ao alcance de seus dedos. Tinha o vento sussurrando promessas em seus ouvidos. Alemão tinha tudo isso. Ele passara a vida tentando abrir aquele cadeado. Quando conseguiu, virou as costas. Em vez de mergulhar na liberdade, desconhecida e sem garantias, Alemão caminhou até o restaurante lotado de visitantes. Pegou uma cerveja e ficou bebericando no balcão. Os humanos fugiram apavorados (BRUM, 2006, 54). 
O antropomorfismo não pára por aqui. A subversiva visita ao zoológico revela que, no cativeiro, os animais se humanizam.

\begin{abstract}
O babuíno sagrado tem um nome comum. Beto. À espreita, lá onde os olhos se misturam com a mente, há o mais perigoso tipo de fúria. A da impotência. Beto dá voltas e mais voltas na jaula, esmurra as grades. Atira comida e fezes nos visitantes. Espanca a companheira se ela não faz tudo o que ele quer. Não admite que emita um som sem a sua permissão. Não deixa que arrede pé sem a sua complacência. Se o faz, Beto cobre-a de tapas. Se a tiram de perto dele, Beto piora. Começa a arrancar pedaços do próprio corpo. Durante as crises, Beto toma dez miligramas de Valium por dia (BRUM, 2006, 55).
\end{abstract}

Das páginas proliferam excêntricas personagens da vida real como Nilsa

Lydia Hartmann, conhecida como Frida, freqüentadora assídua das sessões da

Câmara de vereadores de Porto Alegre, desde os anos 60 .

Filha de agricultores do município de Harmonia. Costureira de mão cheia, um dedo mágico também para plantas e flores. Mãe de seis filhos. Casada com um marceneiro e depois separada. Perseguida por um diagnóstico médico: esquizofrenia. Poderia ter sido confinada em um manicômio. Ou ficar esperando a vida acabar em uma clínica. Preferiu inventar a Frida. E, de algum modo, a família compreendeu. Num mundo que se especializou em esmagar, eliminar e encarcerar a diferença, o melhor para Nilsa era ser Frida.

Se o que Frida compreendeu é coisa de doido, muita gente anda batendo o pino. Frida entendeu que o Legislativo é a sua casa. Interpretou o conceito de cidadania de uma forma tão radical que mais de uma vez foram avistadas suas calcinhas recém-lavadas estendidas sobre as folhagens do jardim. Como às vezes dorme na rua, ela faz uma rápida toalete no banheiro dos motoristas. É também pelos corredores da Câmara que remenda roupas e tricota sapatinhos de lã (BRUM, 2006, 91).

As crônicas de Brum também encontram uma rememoração histórica das vítimas do passado e do presente quando relata a história de David Dubin. Em busca de uma vida que ninguém via, Brum apresenta o outro lado da vida de uma pessoa que todos já viram, a vida

do velhinho dos comerciais. Cabelos de neve, barba de merengue e olhos azuis faiscantes. Um sorriso que parece refletir a paz que a humanidade sonha para o terceiro milênio. Desfiles, anúncios, comerciais de alimentos, de bancos, de companhias telefônicas. Toda vez que as produtoras precisam de um vovô amoroso, de um senhor idoso que alcançou a plenitude da vida com o rosto da saúde e da bonança, é a ele que procuram. O doce velhinho dos comerciais. Com um neto no colo, numa cadeira de balanço, de braço dado na certeza do futuro. Esse é o doce velhinho dos comerciais. Seu nome, Davi Dubin.

Escritor, doutor em Filosofia pela Universidade Federal de São Paulo. Brasileiro, residente em São Paulo-SP. E-mail: dicionariodebabel@hotmail.com 
A autora narra o que ninguém viu nas campanhas publicitárias, o duplo de Davi Dubin, o homem que consegue ser ao mesmo tempo o famoso doce velhinho dos comerciais e uma vítima destroçada do holocausto. No ano de 1944, Davi Dubin, depois de sobreviver à guerra, voltou à cidade polonesa de Pinsk, cidade na qual passara toda sua vida. Do reencontro com seu melhor amigo ouviu: "Davi, como é que ainda não te mataram?". Esta frase precedeu várias descobertas: sua casa não existia mais e 40 pessoas pertencentes à sua família, incluindo sua mãe, mulher e filha de menos de um ano de idade, foram todos mortos.

\begin{abstract}
David descobriu que foram abertas quatro valas em Pinsk, uma em cada canto da cidade. E que todos os judeus foram fuzilados. Todos os 30 mil judeus de Pinsk. E que muitos não morriam e já eram atirados nas valas. $E$ sobre eles eram atirados outros. $E$ morriam asfixiados. $E$ muitos foram enterrados vivos. Primeiro pela massa humana, depois pela terra jogada por cima. Contaram a David que a terra tremia pelo desespero dos que ainda respiravam. $\mathrm{E}$ que por dias a fio o sangue brotava do chão. $E$, por mais que limpassem, a terra seguia parindo sangue porque estava ferida de morte. E porque o sangue era muito (BRUM, 2006, 141).
\end{abstract}

Tal descoberta não seria mais trágica se não tomasse conhecimento ali,

pisando sobre sua vida assassinada, David descobriu que sua família não havia sido morta pelos nazistas. Eles haviam sido apenas mandantes. Sua família foi morta pelos melhores amigos, pelos vizinhos de porta. Pelos ucranianos e lituanos que dividiam seu bairro miserável. Os seus foram mortos por aqueles com quem conviveram por uma vida, com quem haviam trocado as boas e as más notícias, padecido da mesma fome (BRUM, 2006, 141-142).

Contar a história que ninguém via nos anúncios publicitários poderia ser uma tentativa de curar as feridas do passado, cicatrizar o incurável porque 0 personagem da crônica "avisa que não contará toda a história. Porque nunca a contará completa. Porque há coisas que não devem ser ditas. E há tragédias que morrerão com ele. Porque David aprendeu há muito tempo que lembrar é viver de novo" (BRUM, 2006, 142). Trata-se da vida privada de um indivíduo que se mistura com a história contemporânea e do fato de o bom velhinho ter nascido na Europa um pouco antes da meia-noite do século. Segundo a autora, David Dubin nasceu em má hora 
Aos cinco anos, o pai foi fuzilado na Primeira Guerra. No intervalo entre uma e outra, David cresceu apanhando nas ruas por ser judeu, sem conseguir emprego por ser judeu, sem direito ao futuro por se judeu. Sem conseguir casar com a mulher que amava porque era pobre demais. Sem sapatos, comendo um pepino ou um pão duro por refeição. Criado pelo avô, com a mãe e os três irmãos num casebre da cidade polonesa de Pinsk.

Quando chegou a hora de cumprir o serviço militar, atiraram David na cavalariça. Porque não conhecia cavalos. Era o castigo por ser judeu. Aprendeu a domá-los à força de uma vontade de ferro, nascida do riso, das ofensas. Quando domou o primeiro, deixaram de chamá-lo de "judeu" para chamá-lo de Dubin. Foi assim, agarrado às crinas do bicho, que David soube que era um sobrevivente antes mesmo de começar a guerra declarada.

Quando estourou o combate, David lutou com as cores da Polônia. Foi feito prisioneiro de sua tropa. Divididos em filas: judeus de um lado, cristãos de outro. David decidiu salvar-se. Entrou na fila dos cristãos. Foi salvo pelos olhos azuis, os mesmos que hoje encantam nos comerciais de televisão. Depois, ele soube, a sua tropa de hebreus tinha sido castrada e fuzilada.

David Dubin batizou a si mesmo de lan Krinstalski. Foi esse o nome que carregou durante a guerra. A cada noite os arrancavam do galpão e os contavam. O décimo era fuzilado. David fugiu mais de uma vez. Voltou para Pinsk, ocupada então pelos russos, ao final de 1939. E se casou com o seu amor porque era um mundo sem tempo. E fizeram uma filha no meio da morte. Logo, em 1941, os alemães ocuparam a cidade. David foi obrigado a fugir mais uma vez.

Fez trabalhos forçados na Sibéria, caminhou sobre os corpos dos mortos, se alimentou de ratos. Alcançou a sua Pinsk e descobriu que tudo o que ele era estava morto (BRUM, 2006, 143).

Eliane Brum relata também a história de um carregador de malas do aeroporto cujo sonho era voar; do chorador da cidade de Quaraí que ia a todos os enterros da cidade chorar os mortos independentemente se eram pobres ou ricos; de um cego conhecido como Clodair Cauby, por conta do poderio de sua voz, que diariamente gritava, anunciando os prêmios da loteria, com tamanha eloqüência que atrapalhava as aulas de um cursinho pré-vestibular, criando conflito com seus proprietários e alunos, conflito que seguiu até os tribunais; a resistência de Eva Rodrigues ao recusar-se ser vítima por causa da tremedeira que a afligia em decorrência da paralisia cerebral da qual foi acometida ao nascer, seu sofrimento e superação para estudar e formar-se em Pedagogia. A mesma superação que uma mulher de 55 anos, com marido, dez filhos, onze netos e um bisneto, que vivia no interior, teve ao abandonar tudo para realizar o sonho de "procurar as letras" em uma cidade metropolitana que oferecia curso de alfabetização. A autora narra fatos cotidianos como a invisibilidade de um mastigador de vidro em frente ao Mercado Público de Porto Alegre. Brum narra 
histórias das diversas fisionomias forjadas pelo sofrimento daqueles que jamais tiveram a voz ouvida através da relação ingênua entre o ouvinte e o narrador "dominada pelo interesse em conservar o que foi narrado" (BENJAMIN, 1996, 210), histórias de pessoas diferentes e diversas, indivíduos sem fama e glória, sem modelo padrão e norma, oprimidos e outsiders das grandes narrativas históricas, que pouco se importam com o sucesso, a eficiência, o status social, com um suposto "discurso do vencedor", pelo simples fato delas terem superado o acidental e o contingente para manterem-se ainda na vida como um exercício cotidiano de resistência.

\section{Conclusão}

Na contracorrente do "discurso dominante", na época da emergência de notícias e novidades cada vez mais sensacionalistas, contar histórias de pessoas comuns recompõe aspectos de uma narrativa artesanal, pouco preocupada com o progresso e os grandes acontecimentos e mais preocupada com as diferenças, diversidades e adversidades

$\mathrm{Na}$ contramão do homem moderno sem história e sem passado, condenado a viver em um eterno e repetitivo presente por não conseguir memorizar nada, tampouco imaginar um futuro diferente daquele socialmente pré-determinado, Eliane Brum se contrapõe ao mundo que fabrica indivíduos desprovidos de memória. As crônicas-jornalísticas de Brum narram a história daqueles que nunca foram ouvidos e traz o eco traduzido daqueles que não tiveram voz, traz também um narrador sem conselho, que primeiro foi ouvinte e depois um observador, que se "recusa a enxergar apenas o que está programado, o que está na superfície" (BRUM, 2006, 189). Neste sentido, tal olhar se amplia e supera a experiência jornalística, subvertida por apresentar novos sujeitos históricos, fator que amplia a pauta periódica e perene para um sentido polissêmico do próprio ato de reinterpretar o que é e o que não é importante. A autora tem consciência disso no depoimento à Vanessa Bueno, Revista da Cultura - Novíssimo (s/d.): 
Contar a vida de alguém é uma responsabilidade imensa. Como repórter, já tive experiência inacreditáveis, em que pensava: meu Deus, estou vivendo! Mas ainda falta a ficção. Sinto que preciso deixar meus demônios falarem. Sonho em um dia conseguir dinheiro para passar um ano sem trabalhar, só criando. Me relaciono com o mundo escrevendo. Só escrevo sobre assuntos que me interessam. Já derrubei um montão de pautas. Um repórter pode achar que o que ele faz embrulha peixe, ou pensar que é uma testemunha da história. Escolhi ser testemunha.

O trabalho narrativo da autora privilegia as "histórias pequenas" (BRUM, 2006, 189). Conta os "dramas anônimos como os épicos que são, como se cada Zé fosse um Ulisses, não por favor ou exercício de escrita, mas porque cada Zé é um Ulisses. E cada pequena vida uma Odisséia" (BRUM, 2006, 187). Portanto, estas crônicas não se propõem a dar uma moral ou a formular algum ensinamento, estas crônicas se resumem a narrar o presente como realidade concreta, restabelecendo o sentido e o significado atribuído ao passado por meio da formação social e histórica de cada indivíduo, contemplando a sociedade que compõe o cotidiano através de cada um no seu modo de vida.

A narração história de cada um se constrói na vida cotidiana, desde o nascimento em que somos inseridos no cotidiano e enfrentamos suas contingências, dilemas e desafios. O cotidiano apenas não se inventa diariamente, como também se reinventa diante dos fatores históricos, na luta pela alimentação e pelo vestuário, na luta pela matéria e pelo espírito. Desta forma, a história se atualiza nas lutas diárias. No corriqueiro se dá o confronto entre a individualidade e a coletividade, entre opressores e oprimidos. A possibilidade de trazer significado ao presente está no olhar reconstrutor das experiências significativas do passado, construindo a base para uma nova forma de contar histórias, no contexto narrativo moderno, que vê o passado como uma história inacabada que pode ser continuada pelo narrador do presente.

O discurso cronista de Brum privilegia a proximidade para interpretar a experiência do outro e extrair da banal objetividade cotidiana a mais profunda subjetividade humana das pessoas comuns. Não são relatos anedóticos de histórias da vida privada, são histórias particulares que sempre lançam um questionamento permeado por um sentimento de humanidade que questiona $o$ jornalismo factual, a história heróica do passado, os mitos contemporâneos, por trazer consigo as bases do dia-a-dia comum para compor o sentido de vida real. 
Neste contexto, se coloca a presença dos "anônimos da história", pessoas que estão no cotidiano ou fora dos espaços de poder, pessoas que por meio de suas vivências e experiências nos apresentam possibilidades de interpretação sobre a formação histórica e social. Como um cronista que se propõe apenas a contar, Brum capta a história do cotidiano como instantâneos fotográficos que revelam a imagem de sujeitos históricos que a sociedade não quer ver. Na perspectiva benjaminiana, Brum não faz jornalismo, mas história através das facetas do cotidiano que são reveladoras do processo histórico-social brasileiro. Na medida em que constrói um discurso histórico não linear, constituído por fragmentos arrancados do continuum da história, seu texto perde a efemeridade do jornalismo diário e ganha a perenidade do documento histórico, da narração rememorativa. Neste sentido, as crônicas-jornalísticas de Eliane Brum retomam as várias vozes na escrita da história. Neste sentido, seu trabalho narrativo, como uma citation à l'ordre du jour, devolve à história o seu sentido originário: investigação.

\section{REFERÊNCIAS}

AGAMBEN, Giorgio. Infância e história: destruição da experiência e origem da história. Belo Horizonte : Editora UFMG, 2005.

BENJAMIN, Walter. Passagens. Trad: ARON, Irene \& MOURÃO, Cleonice P. B. Minas Gerais: Editora, UFMG, 2006.

São Paulo: Ed. Brasiliense, 1996.

Magia e técnica, arte e política. In_: Obras Escolhidas.

BRUM, Eliane. A vida que ninguém vê. Porto Alegre: Arquipélago Editorial, 2006.

Revista de Cultura, s/d.

. Depoimento à Vanessa Bueno, Revista da Cultura - Novíssimo

FOUCAULT, Michel. A vida dos homens infames. In_: O que é um autor? Lisboa: Veja! Passagens, 1992. 